Okahana, H., Feaster, K., \& Allum, J. (2016). Graduate enrollment and degrees: 2005 to 2015. Washington, DC: Council of Graduate Schools.

Pradel, D. W., Bowles, H. R., \& McGinn, K. L. (2006, February 13). When gender changes the negotiation. Harvard Business School Working Knowledge. Retrieved from: http://hbswk.hbs.edu/ item/when-gender-changes-the-negotiation

Rudman, L. A., \& Glick, P. (1999). Feminized management and backlash toward agentic women: The hidden costs of a kinder, gentler image of middle managers. Journal of Personality and Social Psychology, 77, 1004-1010.

Solnick, S. J. (2001). Gender differences in the ultimatum game. Economic Inquiry, 39(2), 189-200.

Staff, J., \& Mortimer, J. T. (2012). Explaining the motherhood wage penalty during the early occupational career. Demography, 49(1), 1-21.

Trump-Steele, R., Corrington, A., Nittrouer, C., \& Hebl, M. (2017). Convincing men that gender equity matters. Unpublished manuscript, Rice University.

United States Census Bureau. (2016). Income and poverty in the United States: 2015. Retrieved from: https://www.census.gov/data/tables/2016/demo/income-poverty/p60-256.html

U.S. Department of Labor, Bureau of Labor and Statistics. (2017, June). American time use survey summary. Retrieved from: https://www.bls.gov/news.release/atus.nr0.htm

World Economic Forum. (2015). The global gender gap report 2015. Retrieved from: http://reports. weforum.org/global-gender-gap-report-2015/

\title{
Police Shootings and Race in the United States: Why the Perpetrator Predation Perspective Is Essential to I-O Psychology's Role in Ending This Crisis
}

\author{
Mindy E. Bergman \\ Texas A\&M University
}

As I write this essay in mid-September 2017, the news is reporting yet another tragic police shooting that led to the death of a US resident. This time, it was a deaf, nonverbal, Hispanic man in Oklahoma City, Magdiel Sanchez, who happened to be carrying a pipe that he used to fend off stray dogs when he went for walks at night (NewsOK, 2017). To the members of Mr. Sanchez's family and community, his name is the most important part of the previous sentence, but the most terrifying part for the rest of us is the first two words: this time.

It is clear that there is a crisis with police shootings in the United States. There is no government database that tracks police shootings in the US across jurisdictions and types of police agencies. In response, The Washington Post (n.d.a, n.d.b, n.d.c) began tracking police shootings through news

Mindy E. Bergman, Texas A\&M University.

Correspondence concerning this article should be addressed to Mindy E. Bergman, Department of Psychological and Brain Sciences, Texas A\&M University, 4235 TAMU, College Station, TX 77843-4235. E-mail: mindybergman@tamu.edu 
media, public records, and other sources in its "Fatal Force" project. Its reporting indicates that between January 1, 2015 and September 21, 2017 (the time of this writing), ${ }^{1} 2,673$ people were shot and killed by police ${ }^{2}$ in the United States. To put this into perspective for an industrial and organizational (I-O) psychology audience, the number of people killed annually by police shootings is approximately equal to the number of people killed in work-related driving accidents or in the construction industry per year (www.bls.gov). Of these police shooting victims, 95.7\% were men; US Census 2015 projections indicate that men comprised $49.3 \%$ and females comprised $50.7 \%$ of the US population (www.census.gov). The race composition of the group of victims was $48.1 \%$ White (Census: $61.7 \%$ ), $24.5 \%$ Black (Census: 12.4\%), 16.6\% Hispanic (Census: 17.7\%), and 10.8\% other or unknown (Census: $8.2 \%$ other racial groups). Thus, as a group the victims of these shootings are significantly more male and more Black than the general US population.

There is also clear evidence that police shootings occur more frequently by orders of magnitude in the US compared to other Western countries. The Guardian, a UK-based news company, developed a database called "The Counted” that tracked police shootings in several countries (Lartey, 2015). In a telling passage in Lartey's reporting, it states: "The US is not just some outlier in terms of police violence when compared with countries of similar economic and political standing. America is the outlier-and this is what a crisis looks like."

\section{Victim Blaming in Police Shootings}

In this commentary, I agree with Cortina, Rabelo, and Holland's (2018) perspective that victim precipitation models are regressive, troubling, and wrong. Cortina et al.'s critique of the victim precipitation model sheds light on why some police agencies are slow to reform and why the public is slow to demand change: focusing on the victim when explaining the cause of the shooting event. Some of this arises from the news media's creed of being neutral in reporting about events, so they provide information about both the shooter and the victim. It also arises from the continued reification of victim precipitation in our society; that is, the media reflects our national conversation about police shootings by noting whether the victim was armed, fleeing, and so on.

1 Between September 21 and November 6 (the time of revising this commentary), 2017, an additional 110 people were shot and killed by police officers.

2 Note that this does not include people who were shot and not killed, or events in which police drew their weapons and did not fire, or events in which people were killed by police by other means. 
Further, victim blaming arises from individuals' attributional systems (Gilbert, 1998). By focusing on victim characteristics, people are able to construct internal attributions about the victim for the police shooting; this is further bolstered by the number of people who every day encounter police and who are not shot and killed, so our attributional system discourages external attributions relative to the victim, because the victim becomes the distinctive part of the story (Kelley, 1967). From the police agency standpoint, fatal police shootings are not very common within any particular agency relative to their number of contacts with civilians, so the shooting is the unusual event that needs to be explained (i.e., external to the police agency) rather than indicative of policing processes.

Although it is uncomfortable to adopt the phrase "perpetrator predation" (Cortina, 2017) when considering police behaviors, this model is more appropriate and useful for understanding how and why police shootings occur. Note that I am not claiming that police are predators looking to intentionally kill citizens, although this sometimes happens (Berman, Lowery, \& deGrandpre, 2017). Instead, what I am suggesting is that our ongoing preoccupation with the victims of these shootings results in us failing to ask the most important questions that will have the greatest lasting, positive impact on society. It is not just that the shooting victims did certain things, but also that policing policies, training, and practices lead police to see these events and people as threatening at a level that requires deadly force as a response, resulting in a shooting. To change the police shooting problem in the United States, we need to focus on why these events are seen as so threatening, what responses are expected and trained for, and what alternatives could be created in their place. This is not to say that all police aggression against suspects-fatal or not, shooting or not-is unjustified; certainly, some cases must exist in which a police officer would be grievously injured or die unless the suspects were somehow stopped first. But evidence from the rest of the world indicates that although a fatal police shooting might be sufficient, it most certainly is not necessary. To address the police shooting crisis, we must adopt a perpetrator predation perspective.

\section{Race, Racism, and Victim Blaming}

Thus far, I've noted statistics whereby the victims of these shootings are disproportionately Black people, and in particular Black men, but I did not comment on the role of race in these fatal incidents. Eradicating the police shooting crisis in the US will require a number of changes, and notably it will require changing the reactions by police to Black men.

Cortina et al. (2018) noted that the history of the victim precipitation model is littered with sexism and rape mythologies, which serves to support the sex-based social hierarchy. I argue that victim blaming and the adoption 
of the victim precipitation model also serves to support the race-based social hierarchy. In the US, the modern race-based social hierarchy reflects the terrible history of the enslavement of Black people and the formal and legal disenfranchisement of their rights and equal participation in society until the passage of the Civil Rights Act in 1964; in the approximately 50 years following this period, Blacks in the US-and other racial and ethnic minoritieshave had legal equality, but the promise of the Civil Rights Act has not been borne out in practice.

There is ample evidence that White people perceive Black people as threatening and as more threatening than people of other races (e.g., Correll, Judd, Park, \& Wittennbrink, 2002). These effects are amplified when the White person has negative racial attitudes or beliefs (Correll et al., 2002). Similarly, White medical students and healthcare providers believe that Black people can tolerate pain better than White people, resulting in lower pain modulation efforts; these White people's beliefs are based in other erroneous beliefs about Black people's biology and their biological differences from Whites (Hoffman, Tawalter, Axt, \& Oliver, 2016). It is clear that racism is alive and well in the United States, and White people perceive Black people as both inferior and threatening.

How we as a society came to the point where White people perceive Black people as so threatening, when history indicates the opposite to be true, is well-beyond the scope of this short commentary. But suffice it to say that up until 160 years ago, Black people were often property in the United States, so their potential rebellion was personally threatening and their escape was economically threatening to White people; since the end of slavery, their social, political, and economic rise (whether real or perceived) threatened White people's social, political, and economic dominance (which still exists).

By blaming the victims-especially Black victims-for their own fatal police shootings, we continue to reify the race-based social hierarchy in the US and ignore the role that police practices, police training, and police and societal attitudes play in perceiving threat from Black persons, especially Black men. At the individual level, this again probably arises in part from a desire to self-protect via our internal attributions about the victim; it allows us to feel individually safer. But it also arises from the racialized ideas that exist in US culture. At a societal level, victim precipitation permits us to maintain the racial status quo and, for those of us who are rarely targeted by racial prejudice and enjoy the fruits of a race-based social hierarchy, to ignore the racism that exists in the US. By focusing on the victim, we can rest assured that this shooting-and that shooting, and the next, and the next again, and so on-was not because of systematic and systemic problems but because of this one bad actor who brought it on himself. It lets us off the hook 
of confronting individual, systematic, and institutional racism. If we were to change to a perpetrator predation perspective, we would start to ask better questions about police shootings that could get to the heart of this crisis and begin to resolve it.

\section{The Perpetrator Predation Perspective and I-O Psychology}

What can I-O psychologists do to help solve these problems or at least reduce their frequency? The answer is: quite a lot (Ruggs et al., 2016). When we adopt the predator predation framework, then nearly every question about police shootings belongs in the realm of I-O psychology. Instead of asking questions like "What weapon did the victim have at the time of the shooting?" or "Why was the victim fleeing from the police?" we would ask questions like "What training do police officers have to defuse situations in which suspects have weapons and what can we do to improve that training to reduce killings?" or "What procedures should police follow when a suspect is fleeing?" We could also research selection issues, examining whether there are there some people who are less likely to perceive Black men as threatening (and therefore are less likely to shoot them) and whether some people are less likely to engage in police aggression than others (Bergman, Walker, \& Jean, 2016). I-O psychologists would be able to aid police agencies in creating better criterion measures that could include police aggression as an indicator of poor performance. By adopting the predator predation framework, I-O psychologists will provide better solutions to the police shooting problem.

Additionally, as scientists, we have a responsibility to frame our research through the perpetrator predation lens rather than the victim precipitation lens. First, as Cortina et al. (2018) note, the perpetrator predation model is better science than the victim precipitation view, as it avoids the criterion behavior as essential to creating and defining the process. Further, as Cortina et al. note, this reframing can result in the same empirical approaches, but the way that we talk about it, where the onus of responsibility lies, and the practical solutions that we derive from the research will differ. As scientists, we must have constant vigilance regarding our words and framings of the perceptions that people hold about others. As an example, here is a short passage from Hall, Hall, and Perry (2016):

\footnotetext{
In a series of studies, Goff, Jackson, Di Leone, Culotta, and DiTomaso (2014) instructed both undergraduate student and police officer participants to evaluate young Black, White, or Latino suspects and estimate their age and culpability for their actions. Black boys were perceived to be older and less innocent than White boys, and this "adult-like" quality made them appear to be more appropriate candidates for greater use of police force. (p. 176)
}

Note that in the latter sentence, the authors' framing makes it seem as though the "adult-like quality" belongs to the Black boys rather than to the perceptual systems of the participants. The use of the passive voice, although 
common in academic writing, removes the responsible party (i.e., participants) from the sentence and places blame on the victims (i.e., Black boys). This type of writing is insidious, and its presence normalizes the victim as blameful and the perpetrators and perceivers as blameless. Although such language might be difficult for us to recognize due to its normalization through our writing practices and our own attributional tendencies about victims, as scientists we are required to rise above folk psychological explanations for phenomena. This is a basic ethical responsibility.

\section{Conclusion}

As Cortina et al. (2018) note, I-O psychology has been doubling down on the victim precipitation model rather than joining the vast majority of social sciences in their acceptance of the predator predation worldview. This focus on victim characteristics, absent the examination of perpetrator systems, results in narrow and impoverished-if not outright erroneous-explanations of the root cause of abusive or violent events. Herein, I argued that this problem extends to how I-O psychology can help police organizations and the communities they serve, such that failure to adopt the predator predation model will limit our ability to create meaningful and lasting change. I-O psychologists should be leaders in police reform because of our skill set, but until we embrace the predator predation model, we will not be.

\section{References}

Bergman, M. E., Walker, J. M., \& Jean, V. A. (2016). A simple solution to policing problems: Women! Industrial and Organizational Psychology: Perspectives on Science and Practice, 9, 590-597.

Berman, M., Lowery, W., \& deGrandpre, A. (September 16, 2017). Police and protesters clash in St. Louis after former officer who shot black driver acquitted on murder charges. Washington Post [online]. Retrieved from: https://www.washingtonpost.com/news/post-nation/wp/2017/ 09/15/st-louis-tenses-for-verdict-in-murder-trial-of-former-police-officer/?utm_term= .1aa95a470941

Correll, J., Park, B., Judd, C. M., \& Wittenbrink, B. (2002). The police officer's dilemma: using ethnicity to disambiguate potentially threatening individuals. Journal of Personality and Social Psychology, 83(6), 1314-1329.

Cortina, L. M. (2017). From victim precipitation to perpetrator predation: Toward a new paradigm for understanding workplace aggression. In N. Bowling \& M. S. Hershcovis (Eds.), Research and theory on workplace aggression (pp. 121-135). New York, NY: Cambridge University Press.

Cortina, L. M., Rabelo, V. C., \& Holland, K. J. (2018). Beyond blaming the victim: Toward a more progressive understanding of workplace mistreatment. Industrial and Organizational Psychology: Perspectives on Science and Practice, 11(1), 81-100.

Gilbert, D. T. (1998). Ordinary personology. In D. Gilbert, S. Fiske, \& G. Lindzey (Eds.), The handbook of social psychology (4th ed., Vol. 2, pp. 89-150). New York, NY: Random House.

Goff, P. A., Jackson, M. C., Di Leone, B. A. L., Culotta, C. M., \& DiTomasso, N. A. (2014). The essence of innocence: Consequences of dehumanizing Black children. Journal of Personality and Social Psychology, 106(4), 526-545.

Hall, A. V., Hall, E. V., \& Perry, J. L. (2016). Black and blue: Exploring racial bias and law enforcement in the killings of unarmed black male civilians. American Psychologist, 71(3), 175-186. 
Hoffman, K. M., Trawalter, S., Axt, J. R., \& Oliver, M. N. (2016). Racial bias in pain assessment and treatment recommendations, and false beliefs about biological differences between Blacks and Whites. Proceedings of the National Academy of Sciences, 113(16), 4296-4301.

Kelley, H. H. (1967). Attribution theory in social psychology. Paper presented at the 15th annual Nebraska symposium on motivation. Lincoln, NE: University of Nebraska Press.

Lartey, J. (2015, June 9). By the numbers: US police kill more in days than other countries do in years. The Guardian [online]. Retrieved from https://www.theguardian.com/us-news/2015/jun/ 09/the-counted-police-killings-us-vs-other-countries

NewsOK. (2017, September 20). Deaf man shot, killed by police in SE OKC Tuesday. NewsOK [online]. Retrieved from http://newsok.com/police-officers-involved-in-fatal-oklahoma-city-shooting/ article $/ 5564788$

Ruggs, E. N., Hebl, M. R., Rabelo, V. C., Weaver, K. B., Kovacs, J., \& Kemp, A. S. (2016). Baltimore is burning: Can I-O psychologists help extinguish the flames? Industrial and Organizational Psychology, 9(3), 525-547.

The Washington Post. (n.d.a). 2015 Washington Post database of police shootings. Retrieved from https: //www.washingtonpost.com/graphics/national/police-shootings/

The Washington Post. (n.d.b). Police shootings 2016 database. Retrieved from https://www. washingtonpost.com/graphics/national/police-shootings-2016/

The Washington Post. (n.d.c). Police shootings 2017 database. Retrieved from https://www. washingtonpost.com/graphics/national/police-shootings-2017/ 